\title{
EFFECTS OF DIETARY CARBOHYRATE-TO-LIPID RATIOS ON GROWTH PERFORMANCE AND BODY COMPOSITION OF NILE TILAPIA, OREOCHROMIS NILOTICUSL. FINGERLINGS.
}

\author{
Magdy M. Gaber \\ Fish Nutrition Division, National Institute of Oceanography \& \\ Fisheries.
}

Key words : Dietary ration, Growth, body composition, Nile tilapia fingerlings

\section{ABSTRACT}

$\mathrm{S}^{\mathrm{ix}}$ isonitrogenous ( $31 \%$ crude protein), isocaloric $(3.7 \mathrm{kcal} \mathrm{g-J}$ SME), practical diets with variable levels of carbohydrates (starch) and lipids (soybean oil) were formulated to determine the ability of Oreochromis niloticus fingerlings to utilize each nutrients as an energy source. The diets were fed to triplicate groups of fish at a daily rate of $5 \%$ of body weight for 16 weeks. There were significant differences in the growth and feed conversion of Nile tilapia fed diets with carbolyydrate-to-lipid (CHO: L) ratios ranging from 4.8 to 1.22 . A diet containing $\mathrm{CHO}: \mathrm{L}$ ratio of $4.8: 1$ showed significantly lower performance, persumably due to low fat content in the diet. These results indicate that Nile tilapia can efficiently utilize carbohydrate and lipids as an energy source. They can be substituted for onc another at a rate of $2.89: 1$, commensurate with the CHO:L physiological fuel values.

\section{INTRODUCTION}

Protein is responsible for a large part of the cost of prepared diets. Protein utilization has been the main focus of research on nutrient requirements of tilapia (Cruz and Laudencia, 1977; Davis and Stickney, 1978; Mazid et al., 1979; Winfree and Stickney, 1981; Jauncey,1982; De Silva and Perea, 1985; Wang et al., 1985; Siddigui et al., 1988; Shiau and Huang, $1989 \& 1990$ ). The protein fraction should be optimally utilized for growth rather than serve as an energy source for fish. Knowledge of the protein-sparing effects of non- 
protein nutrients such as lipids or carbohydrates is necessary and should be used to reduce costs and maximize nitrogen retention.

Excessive lipid levels in fish diets may reduce fish growth and produce fatty fish (Garling and Wilson, 1977). Essential fatty acid deficient diets also may result in growth retardation and physiological symptoms (Takeuchi and Watanabe, 1977).

Warmwater fishes are able to utilize much higher levels of carbohydrate compared to cold water fishes. However, if adequate carbohydrate in the diet, other nutrients such as protein and lipid may be catabolized for energy, to provide metabolic intermediates for the synthesis of other biological compounds (Gaber, 2000). The concentration of hexokinase, a key enzyme in glucose utilization in animals, is relatively low in fishes (Walton and Cowey,1982). Excess dietary carbohydrate also may lead to fat deposition by stimulating the activities of lipogenic enzymes (Likimani and Wilson, 1982). Therefore, it is important that the proper ratio between carbohydrates and lipids (CHO:L ratio) in fish diet be carefully defined. The purpose of this investigation was to determine the effect of $\mathrm{CHO}: \mathrm{L}$ ratios on growth and body composition of Nile tilapia fed practical, isonitrogenous and isocaloric diets under controlled conditions.

\section{MATERIALS AND METHODS}

\section{Culture conditions and experimental fish}

Nile tilapia, Oreochromis niloticus fingerlings were obtained from the Foka Hatchery, Qalyubia Governorate, Egypt. Fish were acclimatized to laboratory conditions for 4 weeks in fiberglass tanks (water volume1000 L). At the beginning of the experiment, 18 glass aquaria $\left(80 \mathrm{~L}^{-1}\right)$ each was stocked with 15 fish with an average weight of $1.93 \pm 0.03 \mathrm{~g}$ representing six dietary treatments in triplicates. The aquaria were supplied with well water at a rate of $1.5 \mathrm{~min}^{-1}$ with supplemental aeration. The aquaria were illuminated by overhead fluorescent lighting set on a $14 \mathrm{~h}$ light : 10 dark cycle.

\section{Diets and feeding regime}

Six practical isonitrogenous ( $31 \%$ crude protein), and isocaloric $\left(3.7 \mathrm{Kcal} \mathrm{g}^{-1} \mathrm{ME}\right.$ ) diets were formulated (Table 1). Varying levels of carbohydrates (starch) and lipid (soybean oil) were included in the diets. Starch and oil substitutions were made at a rate of 2.89:1, 
commensurate with the carbohydrate-to-lipid physiological fuel values (Garling \& Wilson, 1977). CHO:L ratios ranged from 4.77 to 1.22. The fish were fed at a rate of $5 \%$ of their body weight per day. This amount was close to the maximum daily rations consumed by tilapia during the acclimation period. Fish were weighed every 2 weeks and the amount of feed given was adjusted accordingly. Fish performance, including specific growth rate (SGR), feed conversion ratio (FCR), protein productive value and net energy retention were determined as described by Castell \& Tiews (1980).

\section{Water quality}

During the experimental period, the water was partially exchanged in the morning by removing a part and refilling with new fresh water. Water was aerated to maintain dissolved oxygen level above $3 \mathrm{mgL}^{-1}$. Maximum-minimum water temperatures were recorded daily in one tank, using a mercury thermometer suspended at $30 \mathrm{~cm}$ water depth. Dissolved oxygen (DO) was measured by using aYSI model 58 oxygen meter and $\mathrm{pH}$ using an electronic $\mathrm{pH}$ meter ( $\mathrm{pH}$ pen, Fisher Scientific). Ammonia and nitrite were measured at weekly intervals, and alkalinity and salinity at monthly intervals in one tank per dietary treatment according to Golterman (1977). Sampling was performed between 0700 and $0800 \mathrm{~h}$. before any exchange of water.

\section{Chemical analysis}

Before the beginning of the experiment, 10 fish were randomly removed, weighed and frozen for initial body proximate composition analysis. At the end of the experiment, five fish in each aquarium were randomly selected, weighed and forzen for determination of final body proximate composition. Initial and final body composition analysis were performed, using the standard AOAC (1990) methods.

Lipase activity was determined on fish from different treatments at the end of the feeding trial. The assay was carried out, using fresh intestine tissue of three fish from each replicate aquarium. For this purpose, the fish intestine was cut into three pieces from the anterior to posterior end parts. Weighed tissues were transferred to chilled physiological saline. Intestinal segments were slit open 
longitudinally and washed with cold saline to remove the contents, then homogenized with cold saline in a Potter-Elvehjem type glass homogenizer centrifuge. The homogenate was centrifuged at $6000 \mathrm{xg}$ for $10 \mathrm{~min}^{-1}$ in a refrigerated centrifuge. The cell-free extract collected was used for the assay of lipase activity. The system contained $0.1 \mathrm{M}$ Tris-HCI buffer ( $\mathrm{pH} 7.7) ; 0.2 \%$ anaphtyl laurate in $1: 9$ (acetone: water) as substrate. The assay mixture was incubated for 1 h at $37^{\circ} \mathrm{C}$ in a shaking incubator. The reaction was stopped with addition of one $\mathrm{mL}$. of tetrazotized-o-dianisidine followed by $2 \mathrm{~mL}$ of glacial acetic acid. The absorbance was recorded at $540 \mathrm{~nm}$ in a spectrophotometer (spectronic model no.601), following the method as described by Seligman \& Nachlas (1963).

\section{Statistical analysis}

The data were analysed by one-way analysis of variance (SAS Institute Inc, 1993). Duncan's multiple range test (1955) was used to compare difference among individual means. Treatment effects were considered significant at $\mathrm{P} \leq 0.05$. All percentage and ratio data were transformed to arc sin values before analysis (Zar,1981)

\section{RESULTS}

\section{Water quality}

Water temperature had ranged between $26 \pm 0.7$ to $29 \pm$ $0.05^{\circ} \mathrm{C}$, disolved oxygen ranged between $4.6 \pm 0.4$ to $5.56 \pm 0.2 \mathrm{mg} \mathrm{L} \mathrm{L}^{-1}$ , $\mathrm{pH} 7.4 \pm 0.1$ to $7.8 \pm 0.1$, alkalinity $165 \pm 14$ to $171 \pm 12$. Total ammonia $0.4 \pm 0.1$ to $0.45 \pm 0.2 \mathrm{mg} \mathrm{L}^{-1}$. As no apparent difference in water quality parameters were found among the treatment groups, the data for whole experimental period were pooled. Water quality was found to be within the acceptable range for tilapia growth (Stickney, 1979).

\section{Growth performance}

The performance of Nile tilapia, Oreochromis niloticus fed the diets is summarized in Table (2). All diets produced excellent growth throughout the study (Fig. 1.) Diet A containing 42\% CHO and $8.8 \%$ lipids with a CHO: $L$ ratio of $4.77: 1$ (without oil supplement) produced the poorest growth rates and feed utilization. Increasing lipid contents in the diets to $12.2 \%$ (supplemented with oil $4 \%$ ) 
concomitant with a reduction in $\mathrm{CHO}$ content to $35.3 \%$ (CHO : L ratio of 2.89), significantly improved $(P<0.05)$ growth rates and feed conversion efficiency in Nile tilapia. A further increase in dietary lipids up to $18 \%$ (supplemental oil at $10 \%$ ) with $\mathrm{CHO}: \mathrm{L}$ ratio ranging from 2.16 to $1.22 \%$ did not significantly improve fish performance. Increasing lipid content above $12 \%$ of diet reduced fish growth rates.

Feed conversion ratio (FCR) was decreased then increased with increasing dietary lipid level and was found to differ significantly $(\mathrm{P}<0.05)$ between fish fed 8 to $14 \%$ dietary lipid and 16 to $18 \%$ dietary lipid levels. Protein productive value (PPV) also showed an inverse relationship with dietary lipid level and was significantly higher $(P<0.05)$ in fish fed $10-12 \%$ than in fish fed 16$18 \%$ dietary lipid.

Carcass composition was significantly $(P<0.05)$ affected by dietary lipid (Table 3). Body moisture, protein and ash percentages were negatively correlated with dietary lipid, while body lipid showed a positive correlation as indicated from the linear regression analysis given in Table (4) .

Intestinal lipase activity was increased by increasing oil supplementation in diets. Fig (2) suggests that, higher lipid turnover was reached in fish fed diets C , D , E \& F. This also perhaps indicated that dietary oil at $12 \%$ with a $\mathrm{CHO}$ : L ratio $2.89: 1$ was favoured and therefore appropriate for the growth and well being of this fish species. The differences in activity of lipaze among fish groups fed diet C, D , E \& F was not significant.

\section{DISCUSSION}

The range of dietary $\mathrm{CHO}: \mathrm{L}$ ratios which produced significant effects on Nile tilapia growth and performance in this study $(4.77-1.22)$ was narrower than that found for Tilapia zillii. ElSayed and Garling (1988) fed Tilapia zillii isonitrogenous and isocaloric diets containing variable levels of dietary lipid ranging from $1.7 \%$ to $14.8 \%$ and $\mathrm{CHO}$ ranging from 12 to 14 and found that dextrin could replace lipids in the diets based on physiological fuel values $(2.25: 1)$ at $\mathrm{CHO}$ : $\mathrm{L}$ ratios ranging from (8.76-0.81) without significant effects on fish performance. Higher levels of lipids or 
carbohydrate beyond this range reduced weight gain and protein retention. It appears, therfore, that Oreochromis niloticus can utilize higher levels of $\mathrm{CHO}$ than Tilapia zillii.

Anderson et al. (1984) found that growth rates of Nile tilapia were improved with increasing carbohydrate levels in the diet from to 40\%. El-Sayed and Garling (1988) reported that Tilapia zillii can efficiently utilize carbohydrate as energy sources up to level $36 \%$ of diet . Also, Yone (1979) found that carp could utilize carbohydrate more efficiently than red sea bream and yellow tail. It would appear, therefore, that Nile tilapia can utilize soluble carbohydrate as efficiently as carp and more efficiently than catfish, red sea bream and yellow tail.

It is noteworthy that weight gain of Nile tilapia fed low-fathigh carbohydrate ( $\operatorname{diet} A$ ) was comparable to those fed higher fatlow- carbohydrate diets E\&F (Table 2, Fig.1) but lower than fish fed other tested diets. This decrease in growth of fish fed on diet A may have been related to low fat content. Takeuchi et al. (1983) demonstrated that Nile tilapia require about $0.5 \%$ linoleic acid for maximum growth. Since diet A contained only $8.8 \%$ fat and was not supplemented with fat, it thus contained less than $0.5 \%$ w6 FA. The improvement in fish performance when dietary lipid was rasied to $10 \%$, in diet B may indicate that the EFA requirement of the fish was met at this level.

Nile tilapia may have been able to utilize higher levels of dietary carbohydrate if adequate level of EFAS were available as in $\operatorname{diet} A$. However, this assumption could not be tested, since it was impossible to increase lipid content at the CHO level in diet A and maintain the diet isocaloric. Since all diets in the present study were isocaloric and isonitrogenous, the increase in (PPV) with increasing dietary lipid could be attributed to the relative amount of non-protein energy sources. This may indicate that Nile tilapia despite being herbivorous, can utilize dietary lipid more efficiently than CHO. These results are in complete agreement with those of Hanley (1991) who found that performance of Nile tilapia fed diets containing various levels of lipid (5-15\%) and carbohydrate (31-46) was improved with increasing dietary lipid levels.. Similar observation was reported on rainbow trout (Beamish and Medland,1986). When rainbow trout were fed nutritionally balanced diets, the energy lost as 
heat was decreased with increasing dietary lipids, providing more efficient utilization of protein for growth.

The positive correlation between body lipid and dietary lipid may be indicative that dietary lipid was supplied in excess, as a portion of this lipid was deposited as fat. This is in agreement with the results on rainbow trout (Lee and Putnam,1973), channel catfish (Page \& Andrews, 1973; Garling \& Wilson, 1977), Common carp (Dabrowski, 1977; Takeuchi et al.,1979), Tilapia zillii (El-Sayed and Garling, 1988) and hybrid tilapia (Chou and Shiau, 1996).

The supplement of soybean oil was favoured and therefore appropriate for the growth and well being of this fish species. Such adaptive change in the activity of digestive enzymes has been reported earlier (Mukhopadhyay \& Hajra, 1986; Bazaz \& Keshavanath, 1993).

The common carp, Cyprinus carpio (Takeuchi \& Watanabe,1977). require a mixture of $n-3$ and $n-6$ fatty acids while Tilapia zillii (Kanazawa et al., 1980) require only n-6 fatty acids. Feeding experiments have also shown that the effect of $20: 5 n-3$ and 22-6n-3 on weight gain was superior to $18: 3 n-3$ in channel catfish (Satoh et al., 1989). Such difference has been ascribed to the difference in the capacity for bioconversion of 18:3 n-3 to n-3 HUFAs (Kanazawa el al., 1980).

This study demonstrates that Nile tilapia fingerlings can efficiently utilize both carbohydrate and lipids as energy sources, if they are substituted for one another at a rate of $2: 89: 1$ commensurate with $\mathrm{CHO}: \mathrm{L}$ physiological fuel values. More researches are required to test the ability of Nile tilapia to utilize higher levels of dietary carbohydrate at adequate levels of EFAS.

\section{REFERENCES}

Anderson, J.; Jackson, A. J.; Matty, A. J. and Capper, B. S. (1984). Effects of dietary carbohydrate and fiber on the tilapia, Oreochromis niloticus (linn). Aquacult., 37:303-314. 
AOAC, (Association of Official Analytical Chemists) (1990). Official Methods of Analysis, 14th edition, AOAC, Washington, DC. $1128 \mathrm{pp}$.

Bazaz, M. M. and Keshavanth, P. (1993). Effect of feeding different levels of sardine oil on growth, muscle composition and digestive enzyme activities of mahseer I. Khudree, Aquacult., 115:111-119.

Beamish, F. W. H. and Medland, T. E. (1986). Protein sparing effect in large rainbow trout, Salmo gairdneri. Aquacult.,55: 3542 .

Castell, J. D. and Tiews, K. (Editors) (1980). Report of the EIFAC, IUNS and ICES working group on standardization of methodology in fish nutrient research. Hamburg, Federal Republic of Germany, 21-23 March (1979). EIFAC Tech, Pap. 36:24pp.

Chou, B. S and Shiau, S. Y. (1996). Optimal dietary lipid level for growth of Juvenile hybride tilapia, Oreochromis niloticus $X$ Oreochromis aureus). Aquacult., 143:185-195.

Cruz, E. M. and Laudencia, R. L. (1977). Protein requirements of Tilapia mossambica fingerlings. Kalikasan, $6:$ 177-182.

Dabrowski, K. (1977). Protein requirements of grass carp, Ctenopharyngodon idella. Val. Aquacult., $12: 63-73$.

Davis, A. T. and Stickney, R. R. (1978). Growth responses of Tilapia aurea to dietary protein quality and quantity. Trans. Am. Fish. Soc., $107: 479$ - 483.

De Silva, S. S. and Perea, M. K. (1985). Effects of dietary protein levels on growth, food conversion, and protein use in young tilapia at four salinities.Trans. Am, Fish. Soc., 11 4:584-589.

Duncan, D. B. (1955). Multiple range and multiple F-tests. Biometrics, $11: 1: 42$. 
EFFECTS OF DIETARY CARBOHYRATE-TO-IIPID RATIOS 33 ON GROWTH PERFORMANCE OF NILE TILAPIA, FINGERLINGS.

El-Sayed, A. M. and Garling, D. L. Jr. (1988). Carbohydrate-to-lipid ratio in diets for Tilapia zillii fingerlings. Aquacuit., 73:157-163.

Gaber, M. M. (2000). Optimum exploitation of normal food elements. Review Article. National Institute of Oceanography Fisheries, Cairo, Egypt 71pp.

Garling, D. L.; Jr. and Wilson, R. P. (1977). Effects of dietary carbohydrate-to-lipid ratios on growth and body composition of fingerling channel catfish, Prog. Fish Cult., $39(1): 43-47$.

Golterman, H. L. (ed.) (1977). Methods for chemical analysis of fresh water I. B. P. Hand book No. 8. Blackwell Scientific Publications, Oxford $4^{\text {th }}$ ed. 180pp.

Hanley, F. (1991). Effects of feeding supplementary diets containing varying levels of lipid on growth, food conversion and body composition of Nile tilapia, Oreochromis niloticus (L.). Aquacult., 93:323-334.

Jauncey, K. (1982). The effects of varying dietary protein level on the growth, food conversion, protein utilization and body composition of juvenile tilapia, Sarotherdon mossambicus. Aquacult., 27:43:55.

Kanazawa, A.; Teshima, S. J.; Sakamoto, M. and Awal, M. A. (1980). Requirement of tilapia zillii for essential fatty acids. Bulletin of the Japanes Society of Scientific Fisheries, 46:133-136

Lee, D. J. and Putnam, G. B. (1973). The response of rainbow trout to varying protein energy ratio in a test diet. $J$. Nutr. 103:916-922. 
Likimani, T. A. and Wilson, R. P. (1982). Effects of diet on lipogenic enzyme activities in channel catfish hepatic and adipose tissue. J. Nutr., 112:112-117.

Lovell, T. (Editor), (1989). Nutrition and feeding of fish. Van Nostrand Reinhold, New York. 260pp.

Mazid, M. A.; Tanaka, Y.; Katayama., T.; Asidur Rahman, M.; Simpson, K. L. \& Chichester, C. O. (1979). Growth responses of Tilapia zillii fingerlinges fed isocaloric diets with various protein levels. Aquacult., 18:115-122.

Mukhopadhyay, P. K. and Hajra, A. (1986). Intestinal protease activity and liver protein synthesis in Clarias batrachus fed isonitrogenous diets with variable energy level. Science and Cult., 52:230-233.

Page, J. W. and Andrews, J. W. (1973). Interactions of dietary levels of protein and energy on channel catfish., Ictalurus punciatus. J. Nutr., 103 (9):1339-1346.

SAS Institute Inc. (1993). SAS user's Guide : Basics, Release 6.03. SAS Institute. Inc Carey, NC, USA.

Satoh, S.; Poe, W. E. and Wilson, R. P. (1989). Effect of dietary n-3 fatty acids on weight gain and liver polar lipid fatty acid composition of fingerling channel catfish. J. Nutr., 119: 23-28.

Seligman, A. M. and Nachlas, M. M. (1963). Lipase. In : "Methods of Enzymatic Analysis" (ed. by H. U. Bergmeyer). pp.776778. Academic Press, NewYork.

Shiau, S. Y. and Huang, S. L. (1989). Optimal dietary protein level for hybrid tilapia, Oroechromis nilaticus $x$ Oaureus reared in seawater, Aquacult., 81:119:124. 
Shiau, S. Y. and Huang, S. L. (1990). Influence of varying energy levels with two protein concentration in diets for hybrid tilapia Oreochromis niloticus $x \quad O$. aureus reared in seawater. Aquacult., 91:143-152.

Siddigui, A. Q.; Howlader, M. S. and Adam, A. A. (1988). Effects of dietary protein levels on growth, feed conversion and protein utilization in fry and young Nile tilapia, Oreochromis niloticus. Aquacult., 70:63-73.

Stickney, R. R. (1979). Principles of Warmwater. Aquacult. Wiley Inter. Science, New York.

Takeuchi, T. and Watanabe, T. (1977). Requirement of carp for essential fatty acids. Bulletin of Japanes Society of Scientific Fisheries, 42:893-906.

Takeuchi, T.; Watanabe, T. and Ogino, C. (1979). Availability of carbohydrate and lipid. as dietary energy sources for carp. Bull. Jpn. Soc. Sci. Fish, 45:977-982.

Takeuchi, T.; Satoh, S. and Watanabe, T. (1983). Requirement of Tilapia nilotica for essential fatty acids. Bull. Jpn. Soc. Sci. Fish., 49:1127-1134.

Walton, M. J. and Cowey, C. B. (1982). Aspects of intermediary metabolism in fish. Comp. Biochem. Physiol. B, 73(1): 59-79.

Wang, K. W; Takeuchi, T. and Watanabe, T. (1985). Effects of dietary protein levels on growth of Tilapia nilotica. Bull. Jpn. Soc. Sci. Fish., 51:133-140.

Winfree, R. A. and Stickney, R. R. (1981). Effect of dietary protein and energy on growth, feed conversion efficiency and body composition of Tilapia aurea J. Nutr., 111:1001-1012. 
Yone, Y. (1979). The utilization of carbohydrates by fishes. In G. Yamamoto (Editor), Proc. 7th Japan-Sovit Joint Symp. Aquacult, September (1978). Tohai Univ., Japan.pp. 39-48.

Zar, J. H. (1984). Biostatistical Analysis. Prentice Hall, Inc., Inglewood Cliffs, NJ, 620 pp. 
EFECTS OF DIETARY CARBOHYRATE-TO-HPID RATIOS ON GROWTH PERFORMANCE OF NILE TILAPIA,

FINGERLINGD.

Table 1: Composition and proximate analysis of the practical diets

\begin{tabular}{lcccccc}
\hline & \multicolumn{7}{c}{ Diets } & & & \\
\cline { 2 - 7 } Ingredients (\%) & $\mathrm{A}$ & $\mathrm{B}$ & $\mathrm{C}$ & $\mathrm{D}$ & $\mathrm{E}$ & $\mathrm{F}$ \\
\hline Fish meal (70\% c.p) & 10 & 10 & 10 & 10 & 10 & 10 \\
Meat meal (60\% c.p) & 20 & 20 & 20 & 20 & 20 & 20 \\
Soybean meal (44\% c.p) & 20 & 20 & 20 & 20 & 20 & 20 \\
Wheat bran & 20 & 20 & 20 & 20 & 20 & 20 \\
Corn meal & 9 & 9 & 9 & 9 & 9 & 9 \\
Cellulose & - & 2 & 4 & 6 & 8 & 10 \\
Corn starch & 20 & 16 & 12 & 8 & 4 & - \\
Soybean oil & - & 2 & 4 & 6 & 8 & 10 \\
Premix & 1 & 1 & 1 & 1 & 1 & 1 \\
Total & 100 & 100 & 100 & 100 & 100 & 100 \\
Proximate analysis (\%) & & & & & & \\
Dry Matter & 94.6 & 94.5 & 95.7 & 95.2 & 96.0 & 96.2 \\
Crude protein & 31.8 & 31.7 & 31.6 & 31.6 & 31.6 & 31.6 \\
Crude fat & 8.8 & 10.5 & 12.2 & 14.2 & 16.0 & 18.0 \\
Ash & 7.2 & 7.3 & 8.0 & 8.2 & 8.3 & 8.6 \\
Crude fiber & 4.8 & 6.7 & 8.6 & 10.5 & 13.4 & 16.0 \\
NFE (calculated $)_{\left.\text {ME (Kcal g }{ }^{4}\right)^{4}}^{4}$ & 42.0 & 38.3 & 35.3 & 30.7 & 26.7 & 22.0 \\
CHO : L ratio & 3.7 & 3.7 & 3.7 & 3.7 & 3.7 & 3.7 \\
P/E ratio & 4.77 & 3.65 & 2.89 & 2.16 & 1.67 & 1.22 \\
T & 84.9 & 84.7 & 83.9 & 83.8 & 83.8 & 84.0 \\
\hline
\end{tabular}

${ }^{T}$ Premix supplied the following vitamins and minerals per $\mathrm{kg}$ of feed) vit. A, 8000 I.U ; vit. $D_{3}, 4000$ I.U; vit. E50 I.U; vit. K3. 19 I.U; vit. $\mathrm{B}_{2}$. $69 \mathrm{mg}$ : Nicotinic acid, $125 \mathrm{mg}$; Thiamin. $10 \mathrm{mg}$; Folic acid, $7 \mathrm{mg}$; Biotin, 7mg;vit. $B_{12}, 75 \mathrm{mg}$; Cholin, $400 \mathrm{mg}$; vit C,200mg; Mangancese,350mg; Zinc, 325mg; Iron,30mg; lodince, $0.4 \mathrm{mg}$; Cobalt 2mg; Copper, $7 \mathrm{mg}$; Selenim, $0.7 \mathrm{mg}$ and $0.7 \mathrm{mg} \mathrm{B.H.T.} \mathrm{according} \mathrm{to}$ Lovell, 1989).

${ }^{2}$ Values represent the mean of three sample replicates.

${ }^{3}$ Nitrogen free extract (calculated by difference)

${ }^{4}$ Metabolizable energy based on physiological fuel values of 4,4 and $9 \mathrm{kcal} \mathrm{g}^{-1}$ carbohydrate, protein and lipid, respectively.

${ }^{5}$ Carbohydrate-to-lipid ratio on weight basic $(\mathrm{g} / \mathrm{g})$.

${ }^{6}$ Protein/energy ratio expressed as mg dietary protein per kcal ME 
Table 2: Growth rates, feed conversion ratio of Oreochromis niloticus fed the test diets for 112 days..

\begin{tabular}{|c|c|c|c|c|c|c|c|c|}
\hline $\begin{array}{l}\text { CHO } \\
\text { Lipid }\end{array}$ & $\begin{array}{l}\% \\
\text { Fat }\end{array}$ & Diet & $\begin{array}{c}\text { Initial } \\
\text { weight }(\mathrm{g})\end{array}$ & $\begin{array}{c}\text { Final } \\
\text { weight }(\mathrm{g})\end{array}$ & $\begin{array}{l}\text { Weight } \\
\text { gain (\%) }\end{array}$ & $\mathrm{FCR}^{1}$ & $\begin{array}{l}\text { P.P.V } \\
(\%)^{2}\end{array}$ & $\begin{array}{l}\text { NER } \\
(\% / 2)^{3}\end{array}$ \\
\hline 4.77 & 8.8 & A & $1.93 \pm 0.01$ & $10.4 \pm 0.2^{b}$ & $463.1 \pm 9.3^{b}$ & $2.0 \pm 0$ & $19.2 \pm 0.3^{b}$ & $15.3 \pm 0.3^{c}$ \\
\hline 3.65 & 10.5 & B & & $12.4 \pm$ & $9^{\mathrm{a}}$ & $1.9 \pm 0$ & $22.1 \pm$ & $18.5 \pm 0$ \\
\hline 2.89 & 12.2 & C & & $12.6 \pm$ & 552.5 & $1.9 \pm 0$ & $22.6 \pm 0.3^{\mathrm{a}}$ & $19.1 \pm 0.9^{\mathrm{a}}$ \\
\hline 2.16 & 14.2 & D & $1.94 \pm 0.04$ & $11.7 \pm 0.6^{\text {fb }}$ & 501.9 & $1.9 \pm 0.1^{\mathrm{ab}}$ & $22.7 \pm 1.1^{\mathrm{a}}$ & $19.0 \pm 1.0^{\mathrm{a}}$ \\
\hline 1.67 & 16 & E & $1.93 \pm$ & $11.1 \pm$ & 468 & $2.0 \pm 0.1^{\mathrm{b}}$ & $18.2 \pm 0.2^{\mathrm{b}}$ & $17.9 \pm 0.3^{\mathrm{at}}$ \\
\hline 1.22 & 18 & $\mathrm{~F}$ & $1.94 \pm 0.05$ & $10.8 \pm 0.1^{\mathrm{b}}$ & $457.9 \pm 9.9^{b}$ & $2.0 \pm 0.1^{b}$ & $16.5 \pm 0.1^{\mathrm{bc}}$ & $17.8 \pm 0.2^{\mathrm{b}}$ \\
\hline
\end{tabular}

1- Feed conversion ratio (FCR) $=$ dry feed consumed $(\mathrm{g}) /$ wet wt. gain (g).

2- Protein productive value (PPV) $=100$ (wet protein gain $(\mathrm{g}) /$ protein fed $(\mathrm{g}))$

3- Net energy retention (NER) $=100$ [energy retained Kcal/g ${ }^{-1} /$ energy intake $\left(\mathrm{kcal}^{\left.-\mathrm{g}^{-1}\right)}\right)$ ]

$a, b, c \ldots$ Values in the same column with different superscripts are significantly different $\quad(\mathrm{P}<0.05)$

Table 3 : Body composition of Nile tilapia, (Oreochromis niloticus) fingerlings fed the test diets.

\begin{tabular}{|c|c|c|c|c|c|c|c|}
\hline $\begin{array}{c}\text { Component } \\
\text { \%wcl weight }\end{array}$ & Initial & Final & & & & & \\
\hline Moisture & $78.85 \pm 8.71$ & $78.6 \pm 1.1$ & $78.5 \pm 0.4$ & $78.4 \pm 0.5$ & $78.1 \pm 0.4$ & $79.1 \pm 0.2$ & $78.5 \pm 1.2$ \\
Crude prolein & $12.41 \pm 0.23$ & $15.2 \pm 0.7^{\mathrm{a}}$ & $15.7 \pm 0.1^{\mathrm{c}}$ & $16.3 \pm 0.9^{\mathrm{a}}$ & $14.8 \pm 0.3^{\mathrm{ab}}$ & $14.3 \pm 1.1^{\mathrm{ab}}$ & $13.4 \pm 0.8^{\mathrm{b}}$ \\
Crude lipid & $3.21 \pm 0.29$ & $2.9 \pm 0.2^{\mathrm{d}}$ & $3.4 \pm 0.1^{\mathrm{c}}$ & $3.9 \pm 0.3^{\mathrm{c}}$ & $4.5 \pm 0.1^{\mathrm{ab}}$ & $4.9 \pm 0.1^{\mathrm{a}}$ & $5.4 \pm 0.4^{\mathrm{a}}$ \\
Ash & $2.97 \pm 0.27$ & $2.7 \pm 0.3^{\mathrm{a}}$ & $2.3 \pm 0.1^{\mathrm{c}}$ & $2.3 \pm 0.3^{\mathrm{a}}$ & $2.3 \pm 0.2^{\mathrm{a}}$ & $2.3 \pm 0.1^{\mathrm{a}}$ & $2.3 \pm 0.15^{\mathrm{ab}}$ \\
\hline
\end{tabular}

$a, b, c, d \ldots$ Values in the same row with different superscripts are significantly different $\quad(\mathrm{P}<0.05)$

Table 4: Linear regression analysis of body components of Nile tilapia fed the test diets.

\begin{tabular}{|l|l|c|}
\hline \multicolumn{1}{|c|}{ Component } & Regression equation & Correlation coefficient \\
\hline Moisture & $y=-0.02 X+78.33$ & -0.17 \\
Protein & $y=-0.23 X+18.05$ & -0.78 \\
Ash & $y=-0.03 x+2.77$ & -0.64 \\
Lipid & $y=0.27 x+0.55$ & 0.99 \\
\hline
\end{tabular}


EFECTS OF DIETARY CARBOHYRATE-TO-HPID RATIOS

ON GROWTH PERFORMANCE OF NILE TILAPIA,

\section{FINGERLINGD.}

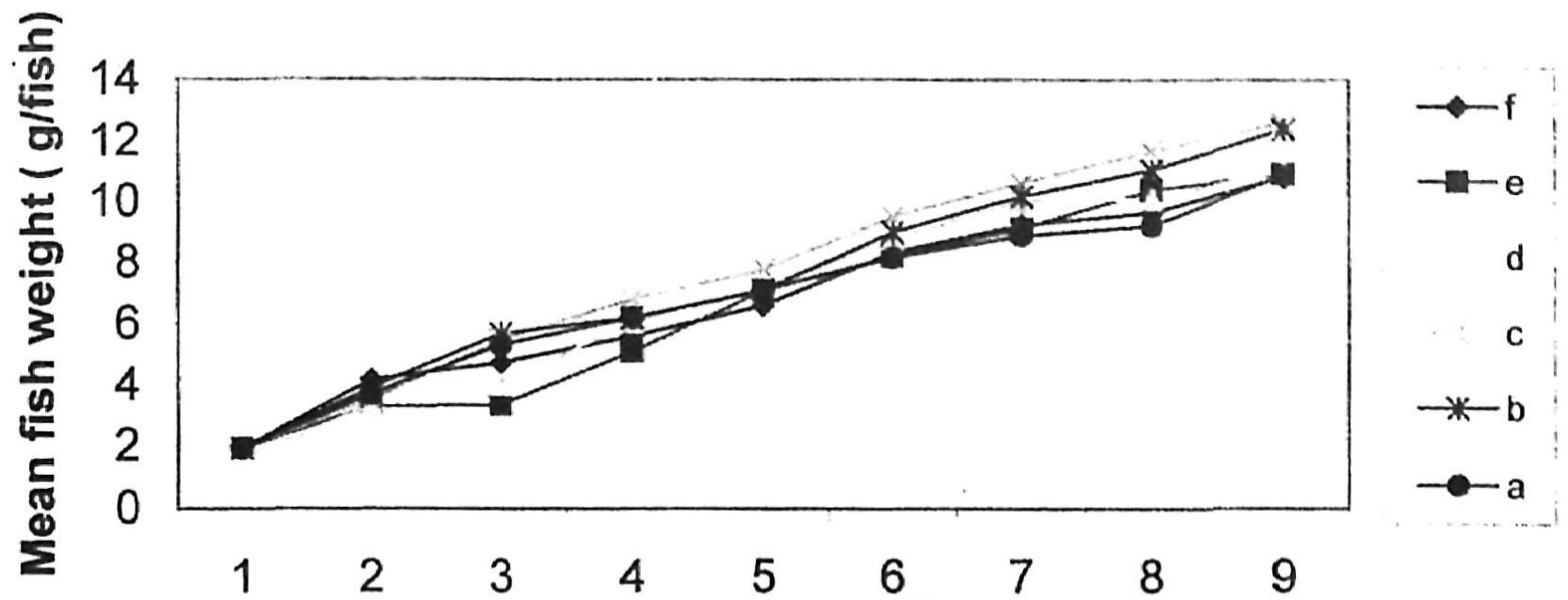

Fig.1. Changes in the weight og O.niloticus fed test diets for 16 weeks

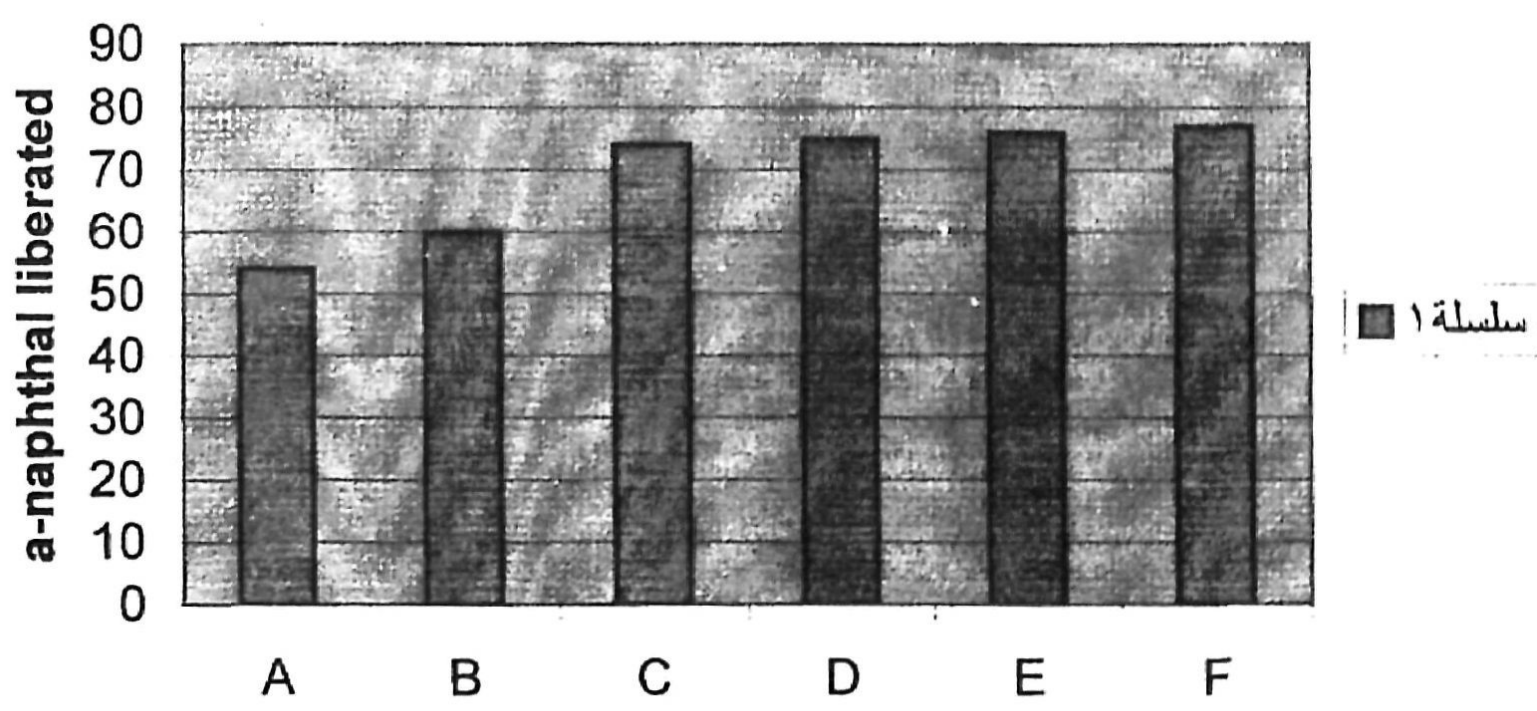

Fig.2. intestinal lipase activity of Oreochromis niloticus under different dietary treatments 